\title{
Fundamental base for assessing the innovative development of a sustainable economy
}

\author{
Sergei $V$. Kochetkov ${ }^{1, *}$ and Olesia $V$. Kochetkova ${ }^{2}$ \\ ${ }^{1}$ All-Russian public organization on the Free Economic Society of Russia, 16, Bolshaya Monetnaya \\ Str., 197101, St. Petersburg Russia \\ 259-11, 78th Guards Division Str., 308510, Razumnoe Village, Belgorod Region, Russia
}

\begin{abstract}
The article is devoted to development of a method for economic evaluation of innovative development. An economic projecting of innovative state has been completed. Theoretical structure of innovative state of the economy has been built, including at the "Entrance" such factors as scientific research and implementation of their results into production, and at the "Output" is the volume of innovative goods, works, services. An economic and mathematical model of Russia's innovative development has been developed. An apparatus of production function and methodology for evaluating of innovative development of the economy is substantiated. The developed methodical set of instruments for regulating effectiveness of innovative development of the economy, including a tessitura, establishing consistent patterns and ensuring its forecasting, serves as a basis for choosing of directions of an economy's restructuring. The obtained results of the research together constitute a technique for evaluating of innovative development at an economy level. On this basis, the developed method for economic evaluating of innovative development consists in an evaluation of effectiveness of expenses of scientific research and evaluation of effectiveness of expenses for implementation their results into production, as well as determining their contribution to the rates of increase of innovative goods, works, and services.
\end{abstract}

\section{Introduction}

Today's agenda dictates the need to transfer the Russian economy to an innovative track, to change its structure in this way. Currently, the innovative state of the Russian economy is characterized by the following peculiarities. The scientific research and the implementation of their results into production have different characteristics and are in various combinations. The interaction of these factors is not fully coordinated with each other in stretch (institutional absence) and time (the rupture between the idea and its implementation in production and mastering by economy); therefore disorder arises in innovative development, which reduces its level. In such structures, when only one factor changes, the growth of the production of innovative goods, works, and services gradually slows down, mainly due to the restrictions created by another unchanging factor. These

*Corresponding author: kochetkovsv.75@gmail.com 
regularities is usually characterized by exponential curves. A constant increase of the innovative goods, works, and services can be ensured only with a simultaneous, more or less proportional change in all factors that determine it.

Currently, various types of indicators and approaches are used for evaluating of the innovative development of the economy $[1,2]$. At the same time, it should be noted that they do not reflect the state of the innovative process as a aggregate, but only consider its separate stages [3]. The process from an idea to its implementation into production and further mastering the economy today, unfortunately, is not the subject of economic science research [4, 5]. Various interdependences of factors are used [6], but the results of innovative development are out of the question. In accordance with fundamental approaches, the evaluating of the innovative development is conditioned by the growth in the volume of the production of innovative products $[7,8,9]$. Today, this is due to the default of appropriate dependencies $[10,11]$.

In this regard, the alignment of the innovative development of Russian economy stipulates of the research objective, which is to design a method for the economic evaluating of innovative development. To achieve this objective, it is necessary to solve the following tasks:

A). Accomplish an economic projecting of the innovative state.

B). Build an economic and mathematical model of the innovative development.

C). Substantiate the selection of directions for restructuring of the economy.

Under current conditions, there is a unique opportunity appears not to return to stagnation, but to move from the crisis to the growth of economy trough the innovative development.

\section{Materials and Methods}

To strengthen the position under consideration, an adequate model of the innovative development of the economy is required, in which its current and opportunities states are considered, that is, to foresee its directions in the near future. This should be the approach to the realization of a method for evaluating the innovative development of the economy.

Wherein the most informative primary indicator should be selected or, if this is not possible, a combined indicator should be created that takes into account the weights of several particular indicators. It is also important that this process is considered from two positions. The first one examines management technologies, actions and procedures that contribute to productive work, methods and mode of managing people, organizing their effective interaction to achieve the defined objectives. The most important objective of the second position is to maintain the general state of stability of the system, stable connections between its various elements and factors. And it should be expressed in the growth of production of the innovative goods, works, and services in our country.

The prospect for solving this problem opens up the that the innovative state is determined by the ability to create, based on the achievements of science, new materials with previously unknown properties, new technological processes, new, more advanced machines and other products. When identifying the parameters and characteristics of the innovative state of the economy, moments should be highlighted that are consistent with the management of a system of any complexity level.

Consequently the model of the innovative state of the economy consists of the following components (Fig. 1): at the "Entrance" - the work of scientists, expressed by the expenses of scientific research, as well as the accumulation of capital, signify in the implementation of the scientific research results into production; "Output" - is determined by the volume of the innovative goods, works, and services. 


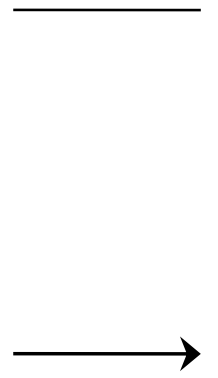

Expenses
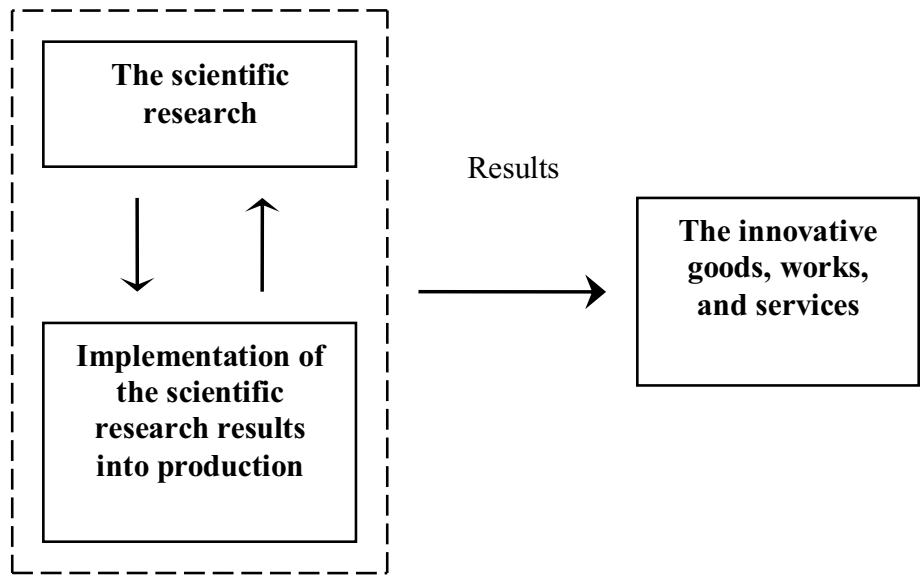

Fig. 1. The model of the innovative state of the economy.

On this basis, a method of the economic evaluating of the innovative development should be consisting in evaluation of the effectiveness of usage of the innovative capacity of the economy. In other words, the process is assessed from the inception of an idea to its implementation into production and, ultimately, the mastering of the results of scientific achievements by the economy.

\section{Results}

\subsection{The technique for evaluating of the innovative development at an economy level}

The comprehensive complex nature of the innovative development of the economy makes its research extremely difficult. In this regard the task arises to highlight the most important and priority issues.

\subsection{The theoretical construction of the innovative state of the economy}

The innovative development of the economy is a necessary prerequisite for the expanded reproduction. In today's conditions, we believe that the vector of the economic development should be redirected towards production, the miscellaneous development of industry.

Reproduction itself should be considered as a concept that determines the modification of elements and states of the system as a condition for its retain and development. This means that for supporting to the system the equal reproduction is necessary, i.e., it will be enough to replace any of its elements to maintain the required level. In turn, the expanded reproduction ensures the development of a system of any level of complexity. In this case, we are talking about a modification in the states of the system as a result of its functioning.

Recently in Russia the opportunities for growth in the volume of the innovative goods, works, services associated with factors such as scientific research and the implementation of their results into production, based on relatively slowly progressing technologies, are 
more or less rapidly narrowing, so that a certain minimum level of the innovative development becomes a defining condition for maintaining the economy.

This theoretical construction of the innovative state of the economy reveals the interconnection between the resources used and the dependence between them, acting as factors used, and the results obtained.

The foregoing confirms that the innovative state of the economy is a starting point, based from which it is possible to find out to what extent the use of the capacity of scientific research and the capacity for implementation its results into production ensures the reproduction of innovative goods, works, services. Adhering to this provision, we should identify the level of influence of the expenses of scientific research and the expenses of implementation their results into production on the growth of the volume of innovative goods, works, services in Russia, as well as the contribution of these expenses to the rate of their increase.

In accordance with the proposed approach, which consists in elucidating the influence of the scientific research expenses and the expenses of implementation their results into production on the growth of the volume of innovative goods, works, services, it seems possible to determine the measure of such impact, which shows its uniqueness. In this regard, the innovative state of the economy is characterized by the following indicators (Table 1).

Table 1. The innovative state of the economy.

\begin{tabular}{|l|l|l|c|c|c|}
\hline \multirow{2}{*}{$\begin{array}{c}\text { Indicator name, } \\
\text { ruble }\end{array}$} & \multicolumn{5}{|c|}{$\begin{array}{c}\text { Analyzed period, } \\
\text { years }\end{array}$} \\
\cline { 2 - 6 } & $\mathbf{1 9 9 1}$ & $\mathbf{1 9 9 2}$ & $\ldots$ & $\mathbf{2 0 1 9}$ & $\mathbf{2 0 2 0}$ \\
\hline $\begin{array}{l}\text { The scientific } \\
\text { research }\end{array}$ & & & & & \\
\hline $\begin{array}{l}\text { Implementation } \\
\text { of the scientific } \\
\text { research results } \\
\text { into production }\end{array}$ & & & & & \\
\hline $\begin{array}{l}\text { The innovative } \\
\text { goods, works, } \\
\text { and services }\end{array}$ & & & & & \\
\hline
\end{tabular}

The scientific research expenditures include expenditures for fundamental research, applied research and development. In turn, the expenses of implementation the results of scientific research into production are the expenses of: research and development of new products, services and methods of their production (transfer), new production processes; production planning, design and other developments (not related to research and development) of new products, services and methods of their production (transfer), new production processes; purchase of machinery and equipment related to technological innovations; acquisition of new technologies, including the patents, licenses to usage inventions, industrial models, utility models; purchase of software; other types of production preparation for the release of new products, the implementation of new services or methods of their production (transfer); education and training of personnel related to innovations; marketing research; other expenses of technological innovation.

It can be said without any exaggeration that the theoretical analysis scheme is based on an evaluation of the contribution of these expenses to the rate in increase of innovative goods, works, and services. In the aggregate these indicators constitute the origins of the formation of the innovative state of the economy and determine the further panorama of the impact on it. 


\subsection{Methodology for evaluating the innovative development of the economy}

The foregoing emphasizes the need for a thorough consideration of the issue of regulating the innovative state of the economy. To substantiate the directions of such regulation, it is necessary first of all to assess the level of innovative development of the Russian economy. To do this, it is necessary to determine the effectiveness of scientific research and the effectiveness of the implementation of their results in production. At the same time, it is important not only to ensure high growth rates of innovative goods, works, services in our country, but also to focus primarily on what sources it is achieved through.

As an attempt to overcome the shortcomings in the existing approaches to the evaluation of innovative development, the essence of the proposed method is to determine the level of the innovative development of the economy, characterized by an evaluating of the rate of increase of the innovative goods, works, and services based on the joint influence of ongoing the scientific research and the implementation of their results into production, that provide them. All stages of the innovative process are being researched from the birth of an idea (initiative, making a proposal) to the practical implementation of innovative products. In the aggregate, this represents the most complete characteristic of the innovative state of the economy. From what has been said, it becomes obvious that the justification of the boundaries of its formating and regulating is carried out within the framework of determining the effectiveness of the scientific research and the effectiveness of the implementation its results into production. Along with this, in order to develop appropriate measures to influence it, it is necessary to find out the contribution of scientific research and the contribution of the implementation of its results into production in the rate of increase of the innovative goods, works, services, and also determine its scale.

The essence of these requirements comes down to identifying and substantiating the regularities of the cumulative influence of factors - the expenses of the scientific research and the expenses of the implementation their results into production - on the reproduction of the innovative goods, works, and services. In general, the innovative development should be considered as a set of basic parameters and characteristics of the innovative state of the economy (object, phenomenon or process) at a certain moment (or interval) of time, with the help of which, in turn, its level can be determined. Consequently, the economy development (object, phenomenon or process) acts as an expansion, a sequential change in its innovative states and the design of a corresponding mechanism of organization and management. This is especially important for the characteristics of dynamic economic structures changing under the influence of various factors and conditions.

The questions of evaluating the effectiveness of the scientific research and evaluating the effectiveness of the implementation their results into production and determining the degree of their complex impact on the rate of increase of the innovative goods, works, and services drew our attention to the theoretical apparatus of the production function.

New tasks bring forward new approaches to their solution. Building the dependence between the volume of the innovative goods, works, and services $(Y)$ and such factors as the scientific research $\left(X_{1}\right)$ and the implementation of their results into production $\left(X_{2}\right)$, we will resort to constructing a production function:

$$
Y=a_{0} \times X_{1}^{a_{1}} \times X_{2}^{a_{2}}
$$

$Y$ - The volume of the innovative goods, works, and services, ruble;

$X_{1}$ - The expenses of the scientific research, ruble;

$X_{2}$ - Implementation of the scientific research results into production, ruble;

$a_{0}$ - innovative reserve (overall factor productivity);

$a_{1}, a_{2}$ - aggregate innovative possibilities. 
The coefficients $a_{0}, a_{1}, a_{2}$ are calculated values in the study of the combinatorial influence of the scientific research and the implementation of their results into production on the rate of increase of the innovative goods, works, and services in the economy. From the above, it follows that the production function set a natural, relatively stable quantitative correlation between the "Entrance" - the expenses of the scientific research and the expenses of implementation their results into production - and the "Output", determined by the volume of the innovative goods, works, and services in Russia economy.

In this regard, for evaluating the interaction of the scientific research and the implementation of their results into production, the following indicators should be used: a) the effectiveness of expenses for scientific research and the effectiveness of expenses for the implementation of their results into production; b) the range of the substitution of resources. A production function analysis is used to calculate these indicators. As a result, we get:

a). Indicators of the ultimate efficiency of resources, which are expressed by the number of units of the innovative goods, works, and services produced per one ruble of the specified expenses:

$$
\begin{aligned}
& \eta_{X_{1}}=a_{0} \times a_{1} \times X_{1}^{a_{1}-1} \times X_{2}^{a_{2}}, \\
& \eta_{X_{2}}=a_{0} \times a_{2} \times X_{1}^{a_{1}} \times X_{2}^{a_{2}-1} .
\end{aligned}
$$

The values of these indicators tell us how much the volume of the innovative goods, works, and services will increase with a change in the specified expenses per unit.

b). An indicator of the resource substitution range, which shows the interchangeability of resources for the same the volume of the innovative goods, works, and services:

$$
\gamma_{X_{1} X_{2}}=\frac{a_{2} \times X_{1}}{a_{1} \times X_{2}} .
$$

The obtained values of the indicator clearly demonstrate how much it is necessary to increase the expenses of the scientific research with a decrease in the expenses of implementation the results of scientific research into production per unit with a constant value of the volume of innovative goods, works, and services.

In the research task the rate of increase of the innovative goods, works, and services signify the level of innovative development, which the indicator of the effectiveness of managing economy.

\subsection{Methodical set of instruments for regulating the effectiveness of innovative development of the economy}

Analysis of the impact on the rate of increase of the innovative goods, works, and services of the components of the innovative state of the economy - the scientific research and the implementation of their results into production - is of fundamental importance for evaluating of the innovative development of our country. With the help of the version of the production function developed by us, we will decompose the rate of increase of the innovative goods, works, and services into the aggregate contribution of factors - the expenses of the scientific research and the expenses of implementation their results into production that influence it (Table 2).

Table 2. The contribution of the scientific research and the contribution of the implementation of its results into production in the growth of the volume of the innovative goods, works, and services. 


\begin{tabular}{|c|c|c|c|c|c|}
\hline \multirow[t]{2}{*}{ Indicator name, $\%$} & \multicolumn{5}{|c|}{$\begin{array}{c}\text { Analyzed period, } \\
\text { years }\end{array}$} \\
\hline & $1991-2000$ & $2001-2010$ & $2011-2020$ & $\ldots$ & $1991-2020$ \\
\hline $\begin{array}{l}\text { The expenses of the } \\
\text { scientific research }\end{array}$ & & & & & \\
\hline $\begin{array}{l}\text { The expenses of } \\
\text { Implementation of } \\
\text { the scientific } \\
\text { research results into } \\
\text { production }\end{array}$ & & & & & \\
\hline $\begin{array}{l}\text { The rate of increase } \\
\text { of the innovative } \\
\text { goods, works, and } \\
\text { services }\end{array}$ & & & & & \\
\hline
\end{tabular}

The calculation by the method of chain substitutions will reveal the measure of such an impact.

The scale of the contribution of the scientific research and the scale of the contribution of the implementation of their results into production demonstrate the degree of usage of their capacity, as well as their impact on the rate of increase of the innovative goods, works, and services for the analyzed period (Table 3 ).

Table 3. The contribution structure of the scientific research and the contribution of the implementation of its results into production in the growth of the volume of the innovative goods, works, and services.

\begin{tabular}{|l|c|c|c|c|c|}
\hline \multirow{2}{*}{ Indicator name. \% } & \multicolumn{5}{|c|}{ Analyzed period, years } \\
\cline { 2 - 6 } & $\mathbf{1 9 9 1 - \mathbf { 2 0 0 0 }}$ & $\mathbf{2 0 0 1 - \mathbf { 2 0 1 0 }}$ & $\mathbf{2 0 1 1 - \mathbf { 2 0 2 0 }}$ & $\ldots$ & $\mathbf{1 9 9 1 - \mathbf { 2 0 2 0 }}$ \\
\hline $\begin{array}{l}\text { The expenses of the } \\
\text { scientific research }\end{array}$ & & & & & \\
\hline $\begin{array}{l}\text { The expenses of } \\
\begin{array}{l}\text { Implementation of } \\
\text { the scientific } \\
\text { research results into } \\
\text { production }\end{array}\end{array}$ & & & & \\
\hline $\begin{array}{l}\text { The rate of increase } \\
\text { of the innovative } \\
\text { goods. works. and } \\
\text { services }\end{array}$ & 100.00 & 100.00 & 100.00 & 100.00 & 100.00 \\
\hline
\end{tabular}

Calculations are made on the basis of the data in the table 2 .

Thus, the regulation of the innovative state of the Russian economy using parameters such as the effectiveness of the scientific research and the effectiveness of the implementation of their results into production, and characteristics - the contribution of the scientific research and the contribution of the implementation of their results into production in the growth of the volume of the innovative goods, works, and services, and especially its scale - allow talking about the design of a new model of the innovative development of the economy. The model we have constructed reveals the impact of these factors on the rate of increase of the innovative goods, works, and services in our country, which, in turn, shows the level of the innovative development of the Russian economy, which characterizes its new quality. 


\section{Discussions}

\subsection{The technique for determining the grade of the innovative development of the economy}

Analyzing the content (interaction of factors) and procedural (trends and patterns) aspects of the innovative development, we come to the conclusion not only about the necessity, but also, most importantly, about the expediency of forming and regulating of the innovative state of our economy.

\subsection{An innovative capacity is the most important factor in the quality of growth at an economy level}

It is extremely indicative that what has been said in aggregate constitutes and substantiates an approach to the formation of the innovative state of the economy, the essence of which is the creating and functioning of the system: the scientific research - implementation of the scientific research results into production, i.e. bringing them to serial samples - the mastering of the results of the scientific achievements by the economy, i.e. their mass production and the sale of the innovative products. In this case, the evaluating of the effectiveness of the previously considered factors reveals the conformity of the scientific capacity to the selected directions of the scientific research. In other words, we get an answer to the question of the timeliness of the development of certain directions of the scientific research.

In turn, the cooperation of these factors, the stability of the communication between them, are determined by such an important task as the regulating of the innovative state of the economy. At the same time, the cooperation of factors is acts as one of the most important means of solving this task. In this regard, their contribution, and especially its scale, clearly demonstrates the vector of the exhaustion of production capacity, that is, they reveal the possibilities of using production capacities for the implementation of the scientific achievements.

The economic and mathematical model of the innovative development of the Russian Federation designed by authors opens up a perspective for solving the research problems. The use of her apparatus reasonable the choice of the most prospect directions for usage of the innovative capacity of the economy, and also indicates the proportionality of its innovative development. This economic and mathematical model reveals the measure of the innovative reserve and the magnitude of the intensification of innovative possibilities. And, as a consequence, it determines the economic structure of the innovative development. In the aggregate, this means that the economic and mathematical model of the innovative development, which I would especially like to note, constitutes an evaluating of the effectiveness of using of the innovative capacity of the economy.

All this convincingly proves that a successful impact (formation and regulation) on the innovative state of the economy will give a original impetus and can start new mechanisms for the innovative development of Russia.

\subsection{The tessitura of the innovative development as an instrument for restructuring of the economy}

Generalize all of the above, we would like to emphasize that the evaluating of the innovative development of the economy is most fully revealed by the indicator of the tessitura. Tessitura of the innovative development of the economy is expressed by the 
correlation of the innovative possibilities and the innovative reserve with the rate of increase of the innovative goods, works, and services. At the same time, the evaluating of the innovative development of the economy consists in the extent to which the use of newly injected resources - the expenses of the scientific research and the expenses of implementation their results into production - influence on rate of increase of the innovative goods, works, and services. Tessitura reveals shows what the correlation of the expenses of the scientific research and the expenses of implementation their results into production provides the maximum of rate of increase of the innovative goods, works, and services. Its dynamics will illustrate this more clearly. The determining factor here is the indicator of the innovative reserve, in the calculation of which it is found out how the available possibilities the influence on the grade of the innovative development of the economy, i.e., how the rate of increase of the innovative goods, works, and services will change with an augmentation in the usage of the available innovative possibilities.

Thus, the tessitura of the innovative development denotes in which direction the impact of one factor or another should be changed. With its help, it seems possible to establish regularities of the innovative development of the economy and explain its forecasts.

As a result, we can say that the grade of the innovative development of the economy is determined by the effectiveness of the usage of the innovative capacity, which is the sum of the innovative possibilities and the innovative reserve.

In the aggregate, the evaluation of the effectiveness of using of the innovative capacity, the determination of indicators of the tessitura and, on this basis, the establishment of the regularities and the forecasting of innovative development are constituted the technique for determining of the grade of the innovative development of the economy.

It is appropriate here to draw attention to the fact that the innovative development of the economy presupposes an cooperation between the science and the production, a constant elevation in its scientific substantiation, while forming the necessary structure of the innovative state of the economy to the achieve a balanced of the rate of increase of innovative goods, works, the services. All this speaks about necessity of considering the question of centralized management of the science and the technique in our country. Today Russia has sufficient the innovative capacity, there are base for ensuring of the sustainable economic growth. At the same time, one should approach this issue in the current conditions with certain prudence.

\section{Conclusion}

\subsection{The mechanism for managing of the innovative development of the economy}

The principal conclusion should be considered that a method of the economic evaluating of the innovative development has been designed, which conclude in the evaluation of the effectiveness of the scientific research expenses and in the evaluation of the effectiveness of implementation their results into production and determining their contribution to the rate of increase of the innovative goods, works, and services.

Using of the designed method of the economic evaluating of the innovative development will highlight the primary directions of integration of the science and the industry in Russia. Based on the calculations of these indicators, it seems possible to formulate and scientifically substantiate the task of the building and the ensuring sustainable development of the spatial-industrial systems. In turn, their functioning will serve as the basis for the design of the concept of the organization and management of the science and the production in our country. 
In the aggregate, this constitutes a new mechanism for managing of the innovative development of the economy.

In total alignment of the innovative development will allow solving the systemic problems facing Russia today and will ensure the economy reaches on new frontiers, that is, it will add it a new quality.

\section{Acknowledgment}

The authors will be grateful for feedbacks and cooperation offers.

\section{References}

1. M. Dziallas, K. Blind, Technovation 80-81, 3-29 (2019) DOI: https://doi.org/10.1016/j.technovation.2018.05.005

2. P. Ganotakis, J.H. Love, The Journal of Product Innovation Management 29(5), 839860 (2012) https://doi.org/10.1111/j.1540-5885.2012.00938.x

3. P.W. Dobson, R. Chakraborty, International Journal of Production Economics 219, 431-439 (2020) DOI: https://doi.org/10.1016/j.ijpe.2018.02.001

4. A. Coad, et al, Structural Change and Economic Dynamics 50, 126-131 (2019) DOI: https://doi.org/10.1016/j.strueco.2019.06.008

5. T.C. Mills, Academic Press 354 (2019) DOI: https://doi.org/10.1016/C2016-0-03956-6

6. A.M. Balisacan, U. Chakravorty, M.-L.V. Ravago, Academic Press 532 (2015) DOI: https://doi.org/10.1016/C2013-0-15316-0

7. M. Brown, On the Theory and Measurement of Technological Change (University Press, Cambridge, 1966)

8. E.F. Denison, The Sources of Economic Growth in the United States and the Alternatives before Us (Committee for Economic Development, New York, 1962)

9. W.J. Baumol, Economic Theory and Operations Analysis. Second Edition. Prentice Hall International Series in Management (Prentice Hall, Englewood Cliffs, N.J., 1965)

10. H. Kelejian, G. Piras, Academic Press 458 (2017) DOI: https://doi.org/10.1016/C2016$0-04332-2$

11. B.M. Fraumeni, Academic Press 554 (2020) DOI: https://doi.org/10.1016/C2018-002037-X 